\title{
Regulation of depth and composition of airway surface liquid
}

\author{
J.H. Widdicombe*+, S.J. Bastacky**, D.X-Y. Wu*, C.Y. Lee**
}

Regulation of depth and composition of airway surface liquid. J.H. Widdicombe, S.J. Bastacky, D.X-Y. Wu, C.Y. Lee. CERS Journals Ltd 1997.

ABSTRACT: The depth and composition of human airway surface liquid (ASL) may depend on secretion from airway glands, ion transport across the surface epithelium, goblet cell discharge, transepithelial gradients in hydrostatic pressure, and surface tension. Published values for the frequency of airway glands and for the secretory rates of individual glands suggest that total gland secretion in human trachea can amount to $\sim 60 \mu \mathrm{L} \cdot \mathrm{cm}^{-2} \cdot \mathrm{h}^{-1}$. Volume absorption directly measured across cultures of surface epithelium from human trachea is $\sim 5 \mu \mathrm{L} \cdot \mathrm{cm}^{-2} \cdot \mathrm{h}^{-1}$. These flows should alter the depth of ASL at +10 and $-1 \mu \mathrm{m} \cdot \mathrm{min}^{-1}$. We have looked for changes in ASL depth of this magnitude using low-temperature scanning electron microscopy (LT-SEM) of rapidly frozen specimens of bovine trachea. Stimulation of gland secretion with methacholine led to an initial increase in depth of $\sim 25$ $\mu \mathrm{m} \cdot \mathrm{min}^{-1}$ followed by a decline at $\sim 1.5 \mu \mathrm{m} \cdot \mathrm{min}^{-1}$. Whereas the initial increase in depth was probably due to transient gland secretion, the later decline reflected active absorption of liquid across the surface epithelium. Finally, we present preliminary data showing that LT-SEM can be combined with X-ray microanalysis to determine the elemental composition of ASL.

Eur Respir J 1997; 10: 2892-2897.
*Children's Hospital Oakland Research Institute, 747 52nd Street, Oakland, CA 94609, +Cardiovascular Research Institute and Dept of Physiology, University of California San Francisco, San Francisco, CA 94143, and **Lawrence Berkeley Laboratory, University of California, Berkeley, CA 94720, USA.

Correspondence: JH. Widdicombe Children's Hospital Oakland Research Institute

747, 52nd Street

Oakland CA 94609

USA

Keywords: Active transepithelial ion transport, airway surface liquid, low temperature scanning electron microscopy, submucosal glands, X-ray microanalysis

Received: February 291997

Accepted after revision April 231997
The airways are lined with a film of fluid, which is 5-20 $\mu \mathrm{m}$ deep in healthy individuals. This fluid is believed to consist of two phases [1]. A watery fluid of low viscosity, the "periciliary sol" surrounds the cilia. Above this lies a viscous mucous gel. The cilia are able to beat in the sol. Their tips contact the underside of the mucous blanket and propel it towards the mouth. This system of "mucociliary clearance" serves to remove particles trapped in the mucous gel. The concept of two layers of airway surface liquid (ASL) has been supported by a variety of microscopy studies [2-5] (fig. 1).

Factors influencing the liquid content of sol and gel have been identified but their relative contributions are imperfectly understood. Water will move into the airway lumen in response to active $\mathrm{Cl}^{-}$secretion across the epithelia of the tracheal surface and of submucosal glands. Active absorption of $\mathrm{Na}^{+}$across the surface epithelium serves to remove liquid. These active ion transport processes move liquid by generating local osmotic gradients across the epithelium [6]. Hydrostatic pressure gradients across the epithelium, and differences in osmotic pressure between the media bathing the epithelium's two surfaces, will also influence the net movement of liquid into or out of the lumen. Evaporation is an important factor in the upper airways. Finally, forces of surface tension generated by the closely packed cilia may serve to hold liquid in the airway lumen [7]. These factors are considered in turn below. Additionally, we describe recent experiments in which we have used lowtemperature scanning electron microscope (LT-SEM) to determine the depth and composition of the airway surface liquid (ASL).

\section{Gland secretion}

The adult human trachea has about 10 submucosal gland openings per $\mathrm{mm}^{2}$ of airway surface [8]. It is unknown how the structure and numbers of glands change down the airways, except that bronchi have glands, whereas bronchioles do not [9]. In each gland, a ciliated duct leads from the airway surface to an expanded collecting duct into which empty $\sim 10$ secretory tubules, each with multiple branches ending in closed acini [10]. The acini are lined by serous cells, the tubules by mucous cells [11]. It is believed that the serous cells secrete fluid which serves to flush out mucins released by the more proximal mucous cells [12]. Consistent with this hypothesis, gland serous cells contain much the highest levels of the cystic fibrosis transmembrane conductance regulator of any cell type in the airways [13]. This protein is an apical membrane $\mathrm{Cl}^{-}$channel involved in transepithelial transport of $\mathrm{Cl}^{-}$and $\mathrm{H}_{2} \mathrm{O}$ [14].

Previous articles in this series: No. 1: P.K. Jeffery, D. Li. Airway mucosa: secretory cells, mucus and mucin genes. Eur Respir $J$ 1997; 10: 1655-1662. No. 2: W.D. Kim. Lung mucus: a clinician's view. Eur Respir J 1997; 10: 1914-1917. No. 3: L.D. Martin, L.G. Rochelle, B.M. Fischer, T.M. Krunkosky, K.B. Adler. Airway epithelium as an effector of inflammation: molecular regulation of secondary mediators. Eur Respir J 1997; 10: 2139-2146. No. 4: R. Wu, Y.H. Zhao, M.M.J. Chang. Growth and differentiation of conducting airway epithelial cells in culture. Eur Respir J 1997; 10: 2398-2403. No. 5: K.C. Kim, K. McCracken, B.C. Lee, C.Y. Shin, M.J. Jo, C.J. Lee, K.H. Ko. Airway goblet cell mucin: its structure and regulation of secretion. Eur Respir J 1997; 10: 2644-2649. 

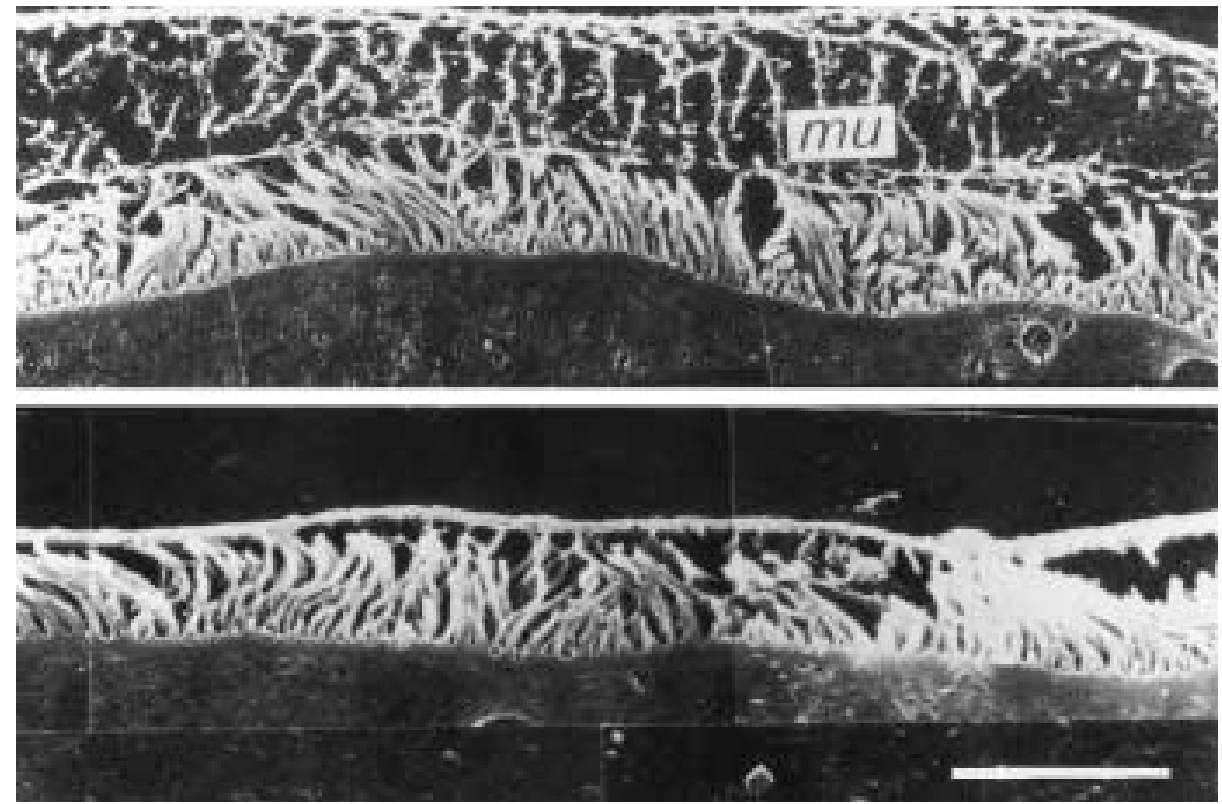

Fig. 1. - Sol and gel layers in cultured rabbit tracheal epithelium. Tissues were rapidly frozen, sectioned, freeze-dried and viewed by scanning electron microscopy. Note that the depth of the sol remains equal to the length of the cilia, though the thickness and consistency of the mucous gel $(\mathrm{mu})$ varies. (Internal scale bar $=10 \mu \mathrm{m}$ ). (From [2], with permission).

The secretory rate of human airway glands is not known. Maximal secretion from individual cat tracheal glands is $\sim 10 \mathrm{~nL} \cdot \mathrm{min}^{-1}[15,16]$. If this rate applies to human tracheal glands, then total gland secretion could be as high as $60 \mu \mathrm{L} \cdot \mathrm{cm}^{-2} \cdot \mathrm{h}^{-1}$. This would increase the depth of the ASL by $\sim 10 \mu \mathrm{m} \cdot \mathrm{min}^{-1}$.

\section{Ion and fluid transport across surface epithelium}

Under unstimulated conditions, the main form of transepithelial solute transport across human airway epithelia is active absorption of $\mathrm{Na}^{+}$[17-19]. Active secretion of $\mathrm{Cl}^{-}$can be induced transiently by several mediators [19]. Its magnitude, however, is less than that of the baseline $\mathrm{Na}^{+}$absorption. Under resting conditions, cultures of airway epithelium absorb fluid at $\sim 5$ $\mu \mathrm{L} \cdot \mathrm{cm}^{-2} \cdot \mathrm{h}^{-1}$ [20], a rate which should reduce the depth of ASL at $\sim 1 \mu \mathrm{m} \cdot \mathrm{min}^{-1}$. Stimulation of $\mathrm{Cl}^{-}$secretion by cyclic adenosine monophosphate (cAMP) or intracellular $\mathrm{Ca}^{2+}$ concentrations $\left(\left[\mathrm{Ca}^{2+}\right] \mathrm{i}\right)$ transiently reduces the rate of fluid absorption, but rarely results in net secretion of liquid [20].

\section{Goblet cell discharge}

Fluid may be drawn into the airway lumen by forces generated by the expansion of mucous granules released by goblet cells [21]. In healthy humans, goblet cells comprise approximately one sixth of the columnar cells of the tracheobronchial epithelium [22]. Gravimetric analysis of tracings of published micrographs suggests that mucous granules occupy $\sim 8 \%$ total cell volume or $\sim 400$ $\mathrm{nL} \cdot \mathrm{cm}^{-2}$ of airway surface. Making the conservative assumption that mucous granules swell tenfold following discharge [21-23], then complete discharge of all goblet cell granules should increase the depth of ASL by $\sim 40 \mu \mathrm{m}$.
ATP is the most potent inducer of goblet cell discharge $[24,25]$. In the guinea-pig trachea, goblet cells are under autonomic control [26]. However, this is probably not the case in humans and most other mammalian species, in which goblet cells discharge only in response to local irritation $[21$, 27].

\section{Osmotic and hydrostatic pressure}

ASL has been variously reported as hypertonic [28] or hypotonic [29] with respect to plasma. Some of the confusion may arise from sampling inadequacies. In the most generally used approach, pieces of filter paper are applied to the airway surface, and withdrawn when saturated. As the paper used is generally much thicker than the depth of ASL, it damages the cells [30], and may sample liquid from the cells and from the interstitium beneath. The most recent estimates of ion content of human ASL suggest that it is hypo-osmotic to plasma [29], thus favouring removal of liquid from the lumen.

The hydrostatic pressure of the airway interstitium is unknown. However, in most other tissues it is $\sim-2 \mathrm{cmH}_{2} \mathrm{O}$ [31]. Again, this would favour movement of fluid from lumen to subepithelial space. However, in asthma, and other types of airway inflammation, there is widespread extravasation in the airways [32], causing the sub-mucosal tissue to become oedematous. Subepithelial pressure is elevated during this extravasation as revealed by the marked dilation of the epithelium's lateral intercellular spaces (LIS) [33]. In other epithelia, pressures of $\sim 20 \mathrm{cmH}_{2} \mathrm{O}$ cause maximal dilation of the LIS [34], while substantially lower pressures markedly increase permeability to water and to solutes as large as proteins $[35,36]$. In dog tracheal epithelium in vitro, pressures as low as $5 \mathrm{cmH}_{2} \mathrm{O}$ increase permeability to water (P. Matsumoto and J.H. Widdicombe, unpublished), albumin and mannitol [37]. Should pressures of this magnitude exist during extravasation in vivo, then the resulting volume flows would account for the excess liquid and blood proteins in the airway lumen during inflammation [38]. Given the dramatic effect of subepithelial hydrostatic pressure on hydraulic conductivity [36], it is likely that hydrostatic pressures generated by extravasation are the prime determinants of transepithelial volume flows during airway inflammation.

\section{Surface tension}

There are 8 cilia $\mu \mathrm{m}^{-2}$ of epithelial surface area [39]. Being $200 \mathrm{~nm}$ in diameter and $6 \mu \mathrm{m}$ in length [39], they will increase the apical membrane surface area by 
$\sim 30$-fold. Surface area is also increased by the numerous microvilli between the cilia. It has been calculated that the forces of surface tension generated by the closely spaced cilia generate a pressure of $\sim 2$ atmospheres [7], corresponding to a concentration gradient of $\sim 40 \mathrm{mOsM}$. This is probably greater than the bulk difference in concentration between ASL and interstitial fluid, and is almost certainly much greater than the local osmotic gradients generated by transepithelial salt transport [6]. In other words, fluid will tend to be held in place between the cilia, and as long as there are cilia there will be a periciliary sol.

\section{Depth of ASL}

Most microscopy methods are inadequate for assessing the depth of ASL. Previous techniques involving chemical fixation of the ASL are subject to several artifacts. Instillation of liquid fixative into the airway lumen may wash away the mucous gel [40, 41], and immersion fixation $[3,42]$ is open to the same criticism. Vascular perfusion allows good maintenance of the structural relationship between ASL and underlying tissues $[41,43]$. However, during fixation by either vascular perfusion or immersion, osmotic gradients will be set up which could alter the depth of ASL. Finally, marked shrinkage of the ASL may occur during the many steps involved in conventional tissue preparation.

Rapid freezing avoids the problems associated with chemical fixation. Frozen tissues, cryosectioned and then freeze-dried and substituted have provided excellent differentiation between the sol and the gel [2, 5]. However, freeze substitution is associated with tissue shrinkage of $11 \%$ in the linear dimension [44], and portions of the ASL may be fractured away during cryosectioning [45]. This approach is therefore of limited use in determining quantitative changes in the depth of ASL.

Rapid freezing combined with low temperature scanning electron microscopy [46] is a technique used to examine cells and bulk tissue samples in the frozen hydrated state. This technique does not distort, substitute or dehydrate any tissue compartments, and it can resolve tissue compartments in the order of $1 \mathrm{~nm}$. Thus, it provides a snapshot in time of the fluid state of the tissue and can be utilized to determine depth of the ASL at various times during physiological stimulation.

After experimenting with various tissues, and several different ways of freezing and handling, we came up with the following approach for using LT-SEM to visualize the ASL [47]. Cow tracheas were obtained from a nearby abattoir within $5 \mathrm{~min}$ of death, and transported to the laboratory at $4^{\circ} \mathrm{C}$ in air saturated with water vapour. An epithelial sheet $\left(\sim 25 \mathrm{~cm}^{2}\right)$ with the submucosal glands intact was dissected away from the underlying cartilage and muscle, and cut into individual 1 $\mathrm{cm}^{2}$ squares which were pinned out, mucosal side up, on sponges saturated with physiological saline, and maintained in a warm $\left(37^{\circ} \mathrm{C}\right)$ humidified atmosphere.

Following a 30 min equilibration period, tissues were frozen when a cryoprobe with a flat polished copper surface, precooled to the temperature of liquid nitrogen $\left(-196^{\circ} \mathrm{C}\right)$ was rapidly brought into contact with the muc- osal surface. Samples were maintained at $<-180^{\circ} \mathrm{C}$, and processed as previously described for frozen pieces of lung [44]. First, probe tip and frozen tissue were rapidly covered with liquid nitrogen. The tissue was trimmed under liquid nitrogen with a high-speed circular dental saw, and mounted in a miniature vice built into a scanning electron microscope (SEM) stub. The specimen holder and tissue were transferred via an airlock to a cryochamber (Biochamber; AMRay, Bedford, MA, USA) attached to the microscope which was maintained under vacuum $\left(10^{-4}\right.$ to $\left.10^{-3} \mathrm{~Pa}\right)$ by a diffusion pump and at liquid nitrogen temperature by a cold shroud and a tank of liquid nitrogen. The specimen was moved within the chamber by a shuttle to an observation window. While viewed by a dissecting microscope, a precooled knife fractured the tissue at right angles to the epithelial surface. If necessary, fracturing was repeated until a clean, smooth fracture plane was obtained. Some samples were coated with gold (20 nm thickness) at this point, whereas others were radiant-etched for periods of up to $1 \mathrm{~min}$ prior to coating. To coat with gold, an electrode assembly was attached to the airlock, and the specimen stub was moved to a copper block immediately under the airlock. If coating was adequate as judged with the dissecting microscope, tissues were transferred from the cryochamber to an SEM stage cooled with a high pressure Joule-Thompson nitrogen refrigerator $\left(<-180^{\circ} \mathrm{C}\right)$. The stage was adjusted until the fracture surface was at right angles to the electron beam.

At high magnification in unetched samples, structural details of the tracheal epithelium, such as nuclei, cilia and mucous granules in goblet cells were evident, and the lining liquid was seen to be $\sim 10 \mu \mathrm{m}$ in depth (fig. 2).

In unetched specimens, it was not possible to distinguish the periciliary sol from the mucous gel because both are probably more than $95 \%$ water. However, if the depth of the airway lining liquid was first increased by stimulating submucosal gland secretion with methacholine, then radiant-etching clearly revealed two layers (fig. 3). The smaller size of the ice crystal voids in the layer furthest removed from the epithelium is consistent with a higher solute (mucin) content of this layer.

In recent studies, we have investigated the effects of submucosal gland secretion on depth of ASL [48]. In control tissues from 10 bovine tracheas, the combined depth of periciliary sol and mucous gel was $23 \pm 3 \mu \mathrm{m}$. On stimulating gland secretion with methacholine, the depth increased to a maximum of $78 \pm 9 \mu \mathrm{m}$ after 2 min exposure. In the continued presence of methacholine, depth thereafter declined approximately linearly with time, reaching $32 \pm 5 \mu \mathrm{m}$ after $30 \mathrm{~min}$. The increase in depth was blocked by bumetanide (an inhibitor of active $\mathrm{Cl}^{-}$secretion). The secondary decrease in depth was blocked by amiloride (a blocker of active transepithelial $\mathrm{Na}^{+}$transport). These results suggest that the methacholine-induced changes in the depth of ASL represent transient gland secretion followed by liquid absorption across the surface epithelium. The increase in depth of $\sim 50 \mu \mathrm{m}$ over the first $2 \mathrm{~min}$ corresponds to a transepithelial volume flow of $150 \mu \mathrm{L} \cdot \mathrm{cm}^{-2} \cdot \mathrm{h}^{-1}$; the decrease in depth of $\sim 40 \mu \mathrm{m}$ between 2 and 30 min corresponds to liquid absorption of $\sim 9 \mu \mathrm{L} \cdot \mathrm{cm}^{-2} \cdot \mathrm{h}^{-1}$. These values are close to our estimate of maximal gland secretion in human trachea of $60 \mu \mathrm{L} \cdot \mathrm{cm}^{-2} \cdot \mathrm{h}^{-1}$ (see above), and also close to 


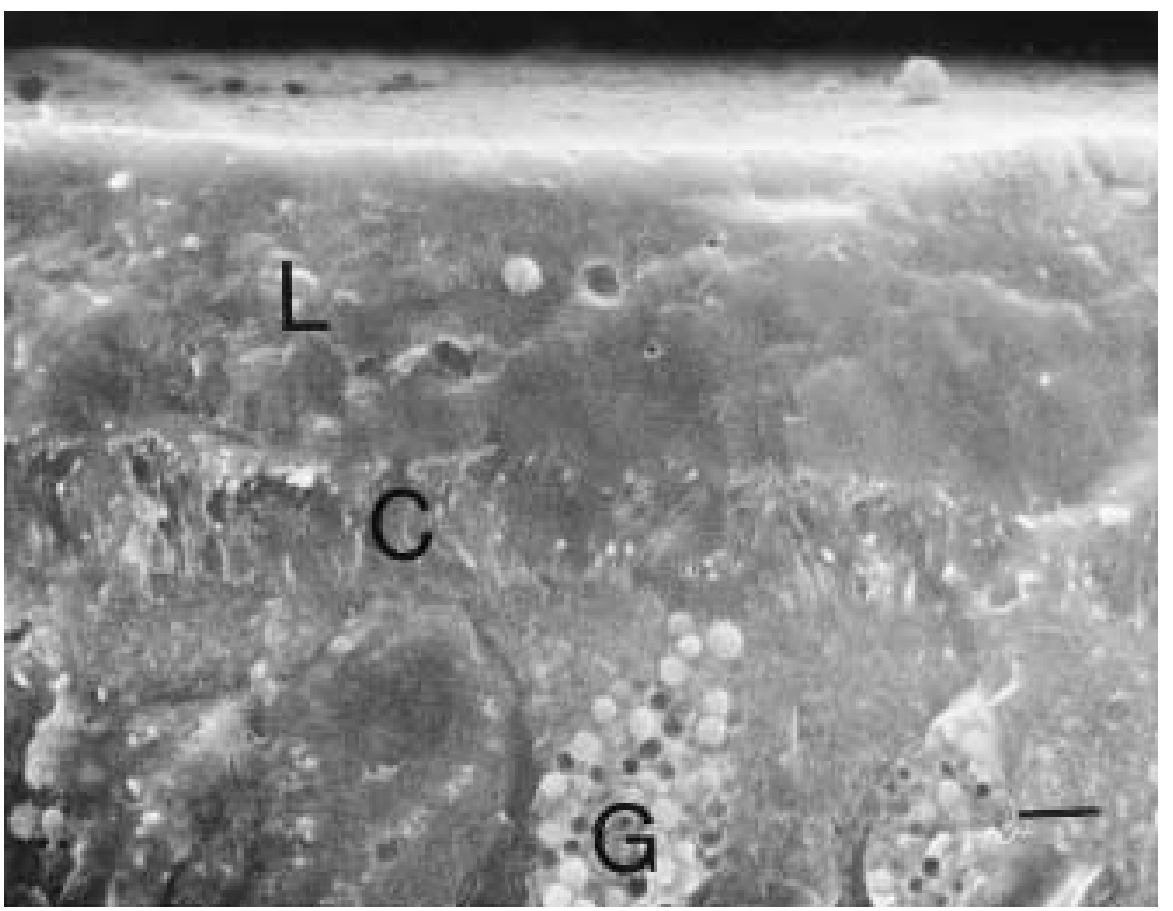

Fig. 2. - Unetched epithelium. L: surface liquid; C: cilia; G: goblet cell. (Internal scale bar=3 $\mu \mathrm{m}$ ). (From [47], with permission).

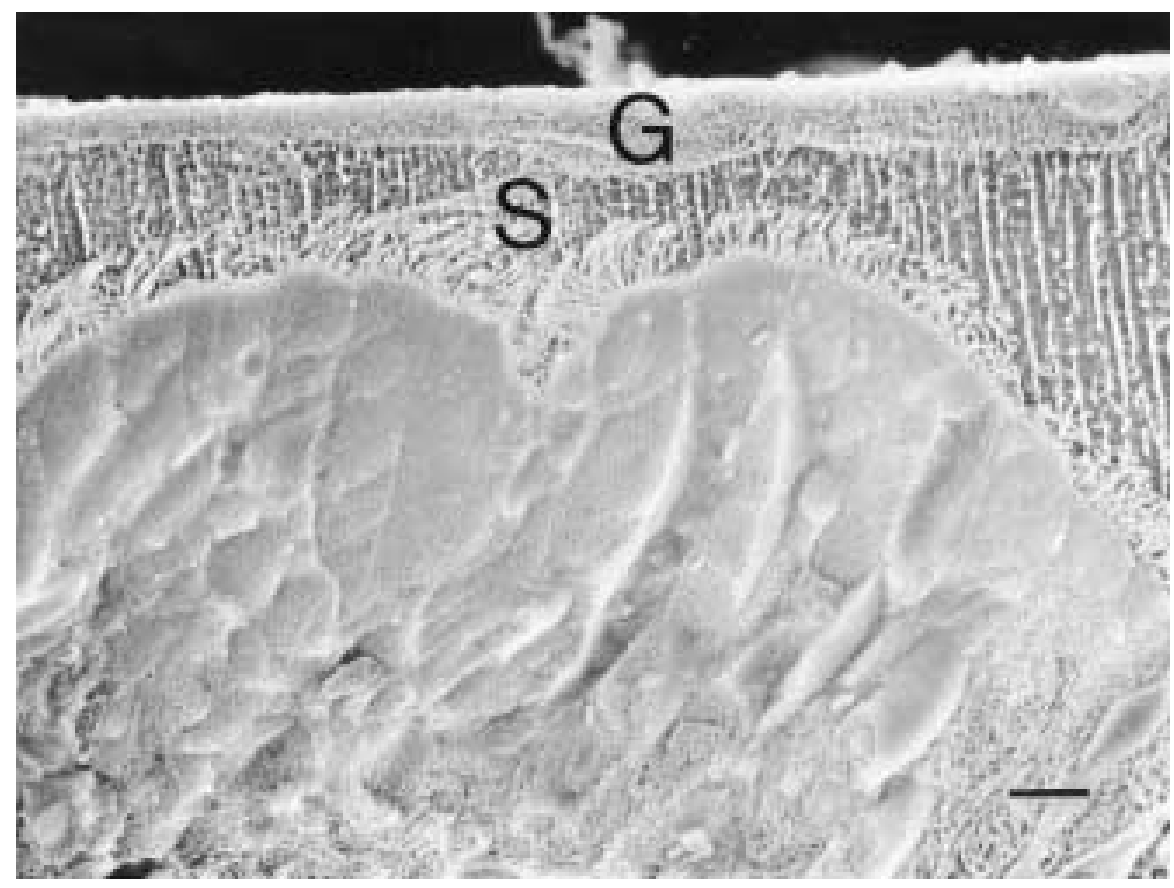

Fig. 3. - Etched epithelium. The airway surface liquid can be differentiated into two layers on the basis of the size of the ice crystal voids. These layers tentatively have been identified as sol (S) and gel $(\mathrm{G})$. (Internal scale bar=8 $\mu \mathrm{m}$ ). (From [47], with permission).

our measured values for fluid absorption across cultures of human tracheal epithelium of $\sim 5 \mu \mathrm{L} \cdot \mathrm{cm}^{-2} \cdot \mathrm{h}^{-1}[20]$. In fact, bovine trachea has twice the density of glands as human trachea (unpublished data), and also double the amount of active $\mathrm{Na}^{+}$absorption across the surface epithelium [49]. Thus, after correction for these interspecies differences, there is excellent agreement between the observed and predicted increases in ASL depth in the bovine trachea in response to methacholine.
In summary, we have shown that LT-SEM can be used to view ASL, while avoiding the problems associated with older microscopic techniques. We found that sheets of bovine tracheal epithelium, when rapidly frozen and viewed by LT-SEM, maintained excellent preservation of epithelial ultrastructure. Radiant-etching distinguished two layers of ASL which we speculate correspond to the sol and gel. Because the current technique involves minimal changes in the dimensions of ASL during processing, it provides a useful approach to determining how changes in gland secretion, goblet cell discharge, and fluid transport by the surface epithelium affect the depth of ASL.

\section{Composition of ASL}

$\mathrm{X}$-ray microanalysis is a technique used to determine elemental composition in numerous materials from biological tissue, to minerals and integrated circuits [50]. Energetic electrons in the beam of an electron microscope displace electrons from inner orbital shells of atoms of the sample. Electrons from outer orbitals drop into the vacated shells and Xrays of energies specific to each element are emitted. X-ray analysers sort incoming X-rays (in counts $\cdot \mathrm{s}^{-1}$ ) according to their energy level and generate a spectrum with Gaussian-like peaks for each element.

In preliminary studies, we have examined freeze-dried Calu-3 cells, an airway cell line that forms tight junctions and shows active secretion of $\mathrm{Cl}^{-}$[51]. When grown without adding medium to the mucosal surface ("air-interface feeding"), Calu-3 cells have a film of liquid on this surface, $\sim 15 \mu \mathrm{m}$ in depth. After drying of the bulk tissue, we noticed that the ASL had shrunk but remained intact. Relatively thick sections ( $~ 50$ $\mu \mathrm{m})$ were taken of the samples. With an accelerating voltage of $200 \mathrm{keV}$, the electron beam penetrates a freeze-dried sample with only a small amount of spreading of the beam. Thus, the volume exposed to the electron beam is known, and reproducible spectra result.

Figure 4 shows X-ray spectra of the ASL and epithelium for Calu-3 cells. The beam current was $6.5 \mathrm{~mA}$ which resulted in an $8.6 \mathrm{~nm}$ beam. The scanned area was 


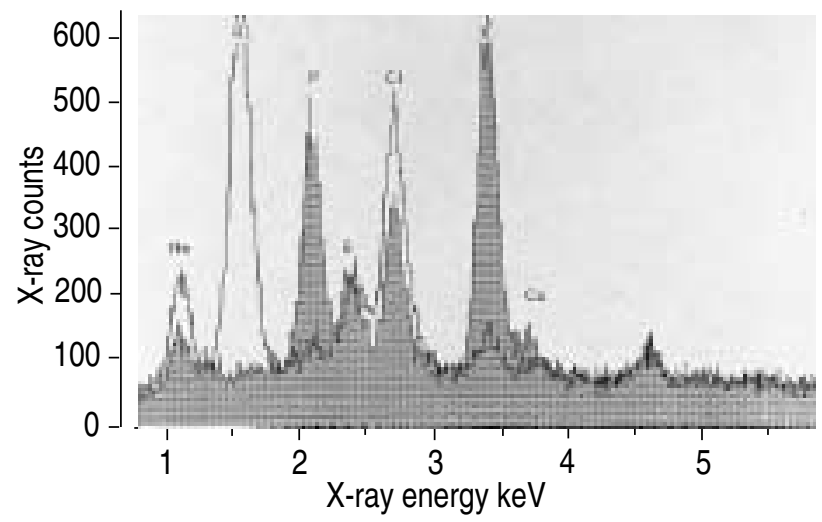

Fig. 4. - X-ray spectra from freeze-dried Calu-3 cells. The ordinate is numbers of X-rays. The abscissa is energy of the X-rays between 0.72 and $5.77 \mathrm{keV}$. The X-ray spectrum from cells is given by the shaded area. The unshaded region is the spectrum from airway surface liquid (ASL). The Al peak in the ASL spectrum comes from aluminum used to coat the mucosal surface of the specimen.

$3 \mu \mathrm{m} \times 20 \mu \mathrm{m}$. Compared to the cells, the ASL shows relatively high $\mathrm{Na}$ and $\mathrm{Cl}$ and very low $\mathrm{K}$ and $\mathrm{P}$ content. The $\mathrm{Na}$ and $\mathrm{Cl}$ signals are sufficiently strong to detect clear-cut differences in $\mathrm{Na}$ and $\mathrm{Cl}$ content between ASL and cytoplasm. We also note that the sulphur signal is well represented in the ASL spectrum, presumably reflecting the presence of sulphate on mucins [52]. Aluminum was used to coat the mucosal tissue surface, and provides a strong signal from the ASL.

We plan to use X-ray microanalysis in several types of study. First, we will measure sulphur levels in the layers which we have tentatively identified as sol and gel on the basis of differences in size of ice crystal voids. If the layers do indeed correspond to sol and gel, the former should have a much lower sulphur peak than the latter. Second, we will see how the elemental composition of airway surface liquid is changed by gland secretion, goblet cell discharge and ion transport across the surface epithelium. Third, we will use human surgical specimens to test the conclusion of others [29] that $\mathrm{Na}$ and $\mathrm{Cl}$ levels of airway surface liquid are higher than normal in cystic fibrosis.

\section{References}

1. Lucas AM, Douglas LC. Principles underlying ciliary activity in the respiratory tract. II. A comparison of nasal clearance in man, monkey and other mammals. Arch Otolaryngol 1934; 20: 518-541.

2. Sanderson MJ, Sleigh MA. Ciliary activity of cultured rabbit tracheal epithelium: beat pattern and metachrony. J Cell Sci 1981; 47: 331-347.

3. Reissig M, Bang BG, Bang FB. Ultrastructure of the mucociliary interface in the nasal mucosa of chicken. Am Rev Respir Dis 1978; 117: 327-341.

4. Yoneda K. Mucous blanket of rat bronchus: ultrastructural study. Am Rev Resp Dis 1976; 114: 837-842.

5. Puchelle E, Beorchia A, Menager M, et al. Threedimensional imaging of the mucus secretory process in the cryofixed frog respiratory epithelium. Biol Cell 1991; 72: 159-166.

6. Diamond JM. Osmotic water flow in leaky epithelia. $J$ Membr Biol 1979; 51: 195-216.

7. Widdicombe JG. Force of capillarity tending to prevent drying of ciliary mucosa. In: Kaliner MA, Barnes PJ, eds. The Airways. New York, Marcel Dekker, Inc., 1988; p. 597.

8. Tos M. Development of the tracheal glands in man. Acta Pathol Microbiol Scand 1966; Suppl. 185: 1-130.

9. Vanpeperstraete F. The cartilaginous skeleton of the bronchial tree. Ergebn Anat 1973; 48: 15-76.

10. Meyrick B, Sturgess JM, Reid L. A reconstruction of the duct system and secretory tubules of the human bronchial submucosal gland. Thorax 1969; 24: 729-736.

11. Meyrick B, Reid L. Ultrastucture of cells in human bronchial submucosal glands. J Anat 1970; 107: 291-299.

12. Widdicombe JH, Shen B-Q, Finkbeiner WE. Structure and function of human airway mucous glands in health and disease. Adv Struct Biol 1994; 3: 225-241.

13. Engelhardt JF, Yankaskas JR, Ernst S, et al. Submucosal glands are the predominant site of CFTR expression in the human bronchus. Nature Genetics 1992; 2: 240-247.

14. Fuller CM, Benos DJ.CFTR! Am J Physiol 1992; 263: C267-C286.

15. Quinton PM. Composition and control of secretions from tracheal bronchial submucosal glands. Nature 1979; 279: 551-552.

16. Ueki I, German VF, Nadel J. Micropipette measurement of airway submucosal gland secretion: autonomic effects. Am Rev Resp Dis 1980; 121: 351-357.

17. Boucher RC, Stutts MJ, Knowles MR, et al. Na transport in cystic fibrosis respiratory epithelia. Abnormal basal rate and response to adenylate cyclase activation. J Clin Invest 1986; 78: 1245-1252.

18. Knowles MR, Murray GF, Shallal JA, et al. Bioelectric properties and ion flow across excised human bronchi. J Appl Physiol 1984; 56: 868-877.

19. Yamaya M, Finkbeiner WE, Chun SY, Widdicombe JH. Differentiated structure and function of cultures from human tracheal epithelium. Am J Physiol 1992; 262: L713-L724.

20. Jiang C, Finkbeiner WE, Widdicombe JH, et al. Altered fluid transport across airway epithelium in cystic fibrosis. Science 1993; 262: 424-427.

21. Verdugo P. Mucin exocytosis. Am Rev Respir Dis 1991; 144: S33-S37.

22. Rhodin JAG. Ultrastructure and function of the human tracheal mucosa. Am Rev Respir Dis 1966; 93: 1-15.

23. Tam PY, Verdugo P. Control of mucus hydration as a Donnan equilibrium process. Nature 1981; 292: 340 342.

24. Kim KC, Nassiri J, Brody JS. Mechanisms of airway goblet cell mucin release: studies with cultured tracheal surface epithelial cells. Am J Respir Cell Mol Biol 1989; 1: 137-143.

25. Davis C, Dowell M, Lethem M, Van Scott M. Goblet cell degranulation in isolated tracheal epithelium: response to exogenous ATP, ADP, and adenosine. Am J Physiol 1993; 262: C1313-C1323.

26. Tokuyama K, Kuo HP, Rohde JA, et al. Neural control of goblet cell secretion in guinea-pig airways. Am J Physiol 1990; 259: L108-L115.

27. Florey H, Carleton HM, Wells AQ. Mucus secretion in the trachea. Br J Exp Pathol 1932; 13: 269-284.

28. Robinson NP, Kyle H, Webber SE, Widdicombe JG. Electrolyte and other chemical concentrations in tracheal airway surface liquid and mucus. J Appl Physiol 1989; 66: 2129-2135.

29. Joris L, Dab I, Quinton PM. Elemental composition of human airway surface fluid in healthy and diseased airways. Am Rev Resp Dis 1993; 148: 1633-1637. 
30. Erjefaldt I, Persson CGA. On the use of absorbing discs to sample mucosal surface liquids. Clin Exper Allergy 1990; 20: 193-197.

31. Wiig H. Evaluation of methodologies for measurement of interstitial fluid pressure (Pi): physiological implications of recent Pi data. Crit Rev Biomed Eng 1990; 18: 27-54.

32. Laitinen LA, Laitinen A, Widdicombe J. Effects of inflammatory and other mediators on airway vascular beds. Am Rev Respir Dis 1987; 135: S67-S70.

33. Laitinen LA, Heino M, Laitinen A, et al. Damage of the airway epithelium and bronchial reactivity in patients with asthma. Am Rev Respir Dis 1985; 131: 599-606.

34. Spring KR, Hope A. Size and shape of the lateral intercellular spaces in a living epithelium. Science 1978; 200: 54-57.

35. House CR. Water Transport in Cells and Tissues. London, Edward Arnold, 1974.

36. van Os $\mathrm{CH}$, Wiedner G, Wright EM. Volume flows across gallbladder epithelium induced by small hydrostatic and osmotic gradients. J Membrane Biol 1979; 49: 1-20.

37. Kondo M, Finkbeiner WE, Widdicombe JH. Changes in permeability of dog tracheal epithelium in response to hydrostatic pressure. Am J Physiol 1992; 262: L176-L182.

38. Brogan TD, Ryley HC, Neal L, Yassa J. Soluble proteins of bronchopulmonary secretions from patients with cystic fibrosis. Thorax 1975; 30: 72-79.

39. Sleigh MA, Blake JR, Liron N. The propulsion of mucus by cilia. Am Rev Respir Dis 1988; 137: 726-741.

40. Nowell JA, Tyler WS. Scanning electron microscopy of the surface morphology of mammalian lungs. Am Rev Respir Dis 1971; 103: 313-328.

41. Luchtel VL. The mucous layer of the trachea and major bronchi in the rat. Scanning Electron Microscopy 1978; 11: 1089-1098.
42. Sturgess JM. The mucous lining of major bronchi in the rabbit lung. Am Rev Respir Dis 1977; 115: 819-827.

43. Hulbert WC, Forster BB, Laird W, Walker DC. An improved method for fixation of respiratory epithelial surface with the mucous and surfactant layers. Lab Invest 1982; 47: 354-363.

44. Bastacky J, Hayes T, Gelinas R. Quantitation of shrinkage during preparation for scanning electron microscope: human lung. Scanning 1985; 7: 134-140.

45. Spencer AJ, Roomans GM. X-ray microanalysis of hamster tracheal epithelium. Scanning Microsc 1989; 3: 505-510.

46. Bastacky J, Goerke J. Pores of Kohn are filled in normal lungs: low-temperature scanning electron microscopy. J Appl Physiol 1992; 73: 88-95.

47. Wu DX-Y, Lee CY, Widdicombe JH, Bastacky J. Ultrastructure of the airway lining layer in lung: lowtemperature scanning electron microscopy. Scanning 1996; 18: 589-592.

48. Wu DX-Y, Lee CYC, Bastacky SJ, Widdicombe JH. Physiological regulation of the depth of airway surface liquid. Am J Physiol (Lung) (in press).

49. Finkbeiner WE, Widdicombe JH. Control of nasal airway secretions, ion transport, and water movement. In: Parent RA, ed. Treatise on Pulmonary Toxicology. Volume 1. Comparative Biology of the Normal Lung. Boca Raton, FL, CRC Press, 1992; 633-657.

50. Jacobsen C, Kenney JM, Kirz J, et al. Quantitative imaging and microanalysis with a scanning soft X-ray microscope. Phys Med Biol 1987; 32: 431-437.

51. Shen B-Q, Finkbeiner WE, Wine JJ, et al. Calu-3: a human airway epithelial cell line which shows cAMPdependent Cl secretion. Am J Physiol 1994; 266: L493L501.

52. Silberberg A, Meyer F. Structure and function of mucus. Adv Exp Mecl Biol 1982; 144: 53-84. 